\title{
INFLUENCE OF TECHNICAL EDUCATION FOR OCCUPATIONAL SAFETY
}

\section{Jiř́ HRBÁČCK - Martin KUČERA}

\begin{abstract}
The safety is affected by many factors. One of the most important are good habits. Training, regulations and penalties for violation of safety does not solve everything if the worker has bad habits. When should I start with creating a safe work attitude, respect and proper work practices and safe handling of machinery and tools? In this area pay more than anywhere else, the sooner the better. It is therefore necessary to devote to this area from an early age pupils. It is at this age children are very sensitive to the examples of their surroundings. The paper analyzes the results of the review options for a positive impact on pupils in relation to OHS.
\end{abstract}

Key words: safety, good habits, early age pupils.

\section{VLIV TECHNICKÉ VÝCHOVY NA BEZPEČNOST PRÁCE}

Resumé: Na bezpečnost práce má vliv mnoho faktorů. Jedním z nejvýznamnějších jsou správné návyky. Školení, nařízení a postihy za nedodržování bezpečnosti při práci neřeší vše, pokud má pracovník špatné návyky. Kdy je třeba začít $\mathrm{s}$ vytvářením postoje $\mathrm{k}$ bezpečné práci, $\mathrm{k}$ dodržování pracovních postupů a správným a bezpečným zacházením se stroji a nástroji? $\mathrm{V}$ této oblasti platí více než kdekoliv jinde, čím dřive tím lépe. Je tedy třeba se této oblasti věnovat již od raného věku žáků. Právě v tomto věku žáci velmi citlivě reagují na př́íklady ze svého okolí. Př́spěvek analyzuje výsledky zkoumání možnosti, jak pozitivně působit na žáky ve vztahu k BOZP.

Klíčová slova: bezpečnost práce, dobré návyky, raný věk žáků.

\section{1 Úvod}

V rámci pořádání technických kurzů na dvou základních školách v okolí Brna jsme mimo jiné také zkoumali, jak jsou žáci zvyklí dodržovat zásady bezpečnosti a ochrany zdraví při práci v dílnách. Zjišt'ovali jsme jejich návyky, chování, zacházení $\mathrm{s}$ nástroji i udržování pořádku na pracovištích. Cílovou skupinou byli žáci šesté až osmé tř́dy.

\section{Péče o nástroje a práce s nimi}

Ukázalo se, že žáci jsou informováni o způsobu používání základních pracovních nástrojů, jako je kladivo, šroubovák, pilník a pilka na kov. Práce s těmito nástroji pro ně však není samozřejmá a používají je spíš intuitivně, než cíleně. Zacházení se svěrákem, v závislosti na materiálu obrobku, neznají. Neví, kdy použít hliníkové vložky do čelistí a povědomí o možném poškození materiálu čelistmi svěráků jim není vlastní. Stejně tak nemají zažito jak o svěrák pečovat. Jako jedinou péči o nástroje, kterou znají, lze považovat schopnost po práci nástroje uklidit do zásuvky stolu. Nevnímají však jakékoliv zásady týkající se uložení nástrojů, aby se vzájemně netupily a nepoškozovaly. Nejsou zvyklí nástroj před prací zkontrolovat a oveřit si, zda je $\mathrm{v}$ pořádku.

\section{Chování a práce v dílně}

Bylo zjištěno, že ani $\mathrm{v}$ této oblasti pro ně zásady správného a bezpečného chování v dílně a bezpečného zacházení $\mathrm{s}$ nástroji nejsou samozřejmostí. Pobíhání, "šermování" s nástroji, přebíhání mezi pracovními místy, obtěžování spolužáků při práci, to jsou jevy, které $\mathrm{v}$ dílně vidíme nezřídka. Učitel ve výuce musí tedy bedlivě toto chování sledovat a žáky neustále upozorňovat, co mají a co nesmí.

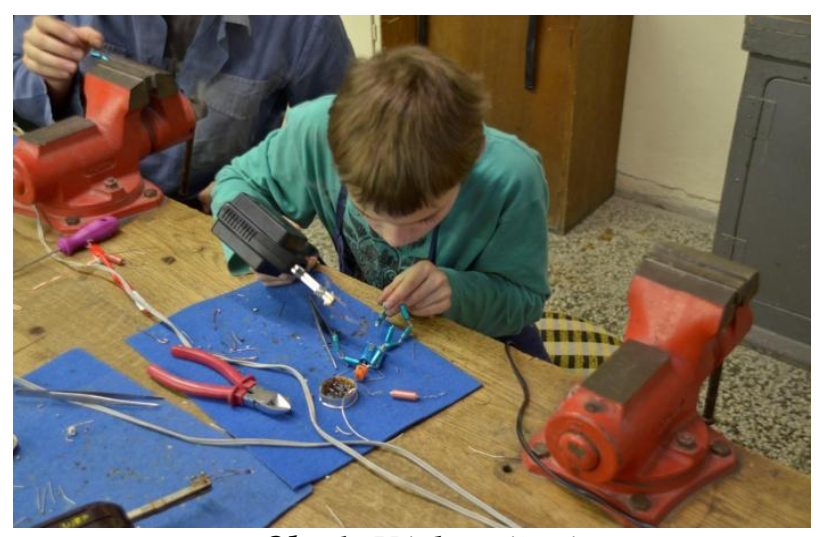

Obr 1: Výuka pájení. 


\section{Správné ustrojení a používání ochranných pomůcek}

$\mathrm{Z}$ tohoto pohledu je situace o trochu lepší. Žáci jsou zvyklí používat pracovní zástěry, pokud však jde o vlastní oblečení, v kterém do dílny přicházejí, spokojenost není na místě. Ani žáci, ale obvykle ani rodiče své žáky do výuky v dílnách správně nevybaví. Nosí drahé světlé oblečení, které má na sobě různé šňůrky. Majî řetízky na krku a rukou. Pozitivní je, že nosí alespoň uzavřenou sportovní obuv. Ve zkoumané skupině nebyly dívky, proto nebyl problém s dlouhými vlasy a pokrývkou hlavy.

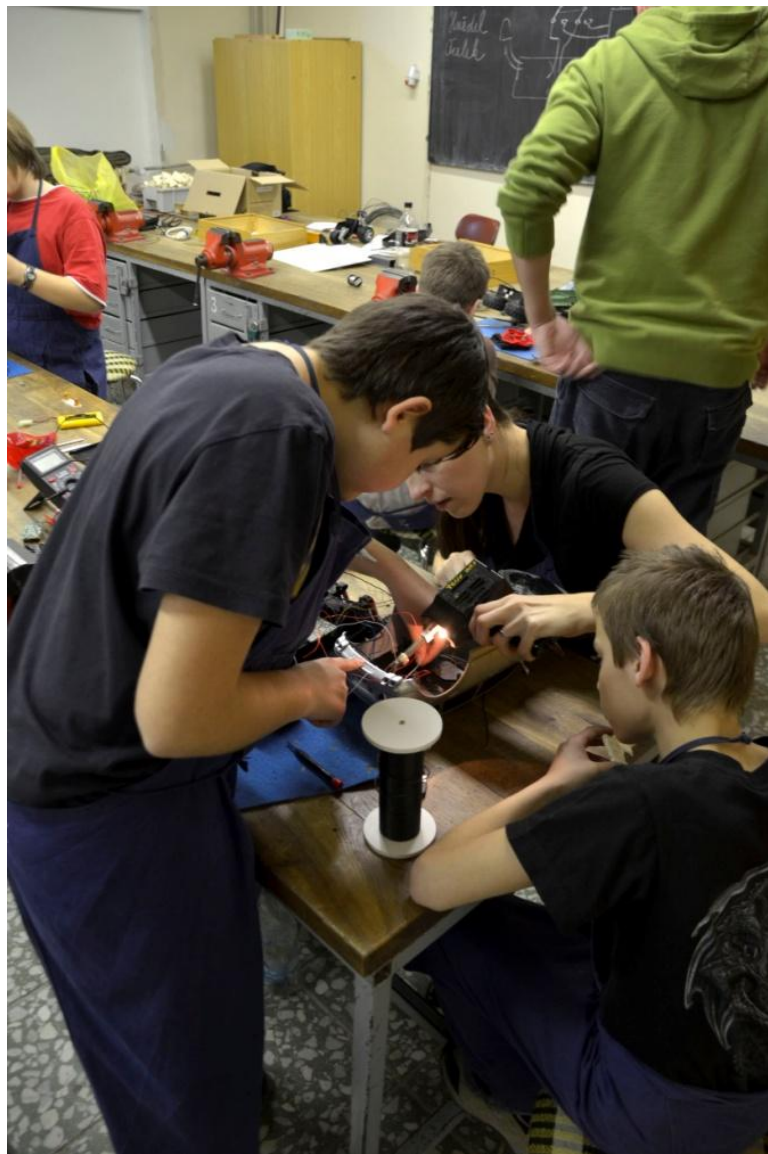

Obr 2: Spolupráce při montáži elektroniky do robota.

\section{Práce s ruční vrtačkou a trafopáječkou}

Ruční vrtačku většina žáků zná a již s ní pracovali. Pokud však jde o bezpečnost práce s tímto elektrickým ručním nářadím a zručnost při jeho použivání, nelze to napsat jinak, než že je to noční můra učitele. Dá se říct, že pouze jeden z deseti žáků s elektrickou ruční vrtačkou umî bezpečně zacházet. Totéž platí i pro její údržbu včetně péče o vrtáky.

S trafopáječkou se chlapci seznámili již při výuce fyziky, ale jak tvrdili, tam používali jinou (nebylo jasné jakou). Zacházení s ní a technika pájení byla pro ně zcela neznámá.

\section{Návrh a ověření metodiky práce s nářadím}

Na základě zjištěných skutečností byl navržen následující postup.

Je třeba žáky již při nácviku jednotlivých pracovních operací pečlivě vést $\mathrm{k}$ dodržování správného zacházení $\mathrm{s}$ nástroji a nářadím. Použivání ochranných pomůcek i správného oblečení. V žádném případě nesmí být opomenuta starost o náŕadí a jeho údržba i pravidelná kontrola.

Je tedy třeba

- nejdř́ve podrobně seznámit žáky s nástrojem, jeho kontrolou a používáním

- dbát na pečlivost, přesnost a soustředěnost při práci

- dbát na správné používání nástrojů, nářadí a ochranných pomůcek

- nedovolit zbytečný pohyb po dílně a přebíhání mezi pracovišti

- vyžadovat maximální kvalitu práce (v závislosti na schopnostech žáka)

- pokud se něco nepovede, vyrobit výrobek znovu

- aby žáci poznali, jak se pracuje se špatným a jak s dobrým nástrojem a jaká další rizika vadné nástroje přináší

- aby žák věděl, jak nástroj uložit a po práci ošetřit

- průběžné udržování pořádku na pracovišti

V průběhu kurzů byly tyto zásady striktně dodržovány a po žácích vyžadovány

\section{Výsledky, kterých bylo dosaženo}

První výsledky na sebe nedaly dlouho čekat. Už druhý týden (po čtyřech hodinách trvání kurzu) se žáci sami po príchodu do dílny převlékli, pomohli s př́pravou nářadí a nástrojů. Můj př́stup byl přísný a důsledný. Nedovolil jsem žádnou diskusi ohledně stanovených pravidel a tvrdě je vyžadoval. Tvrdě, ve smyslu, při prvním porušení pravidel jsem zastavil práci a ostře připomenul, co lze a co nikoliv. Bylo třeba asi pouze dvou takovýchto zásahů a chlapci přesně věděli, co mohou a co ne. Pak již až do konce kurzů nebylo třeba takto vystoupit a šlo vše docela $\mathrm{v}$ klidu. Panovala kamarádská atmosféra a kurz všechny bavil. 
Po ukončení kurzu bylo setkání s žáky i jejich rodiči. Provedli jsme společně rekapitulaci kurzu, $\mathrm{s}$ každým žákem si jeden z mých studentů, kteří na kurzu asistovali a $\mathrm{s}$ chlapci pracovali, o samotě probral jeho pohled na proběhlý kurz a stejně tak $\mathrm{s}$ každým $\mathrm{s}$ rodičů jsme provedli řízený rozhovor. Prezentovat, prostřednictvím tohoto příspěvku, všechny závěry i vlastní průběh výzkumného šetření, není z prostorových důvodů možné.

Z pohledu BOZP však lze konstatovat následující závěry. Výzkum prokázal, že cílená, pečlivá a systematická práce $\mathrm{s}$ důsledným dodržováním zásad práce, používání bezpečnostních pomůcek i zásad správného oblékání a chování v dílně je cestou správnou. U žáků se tak vytvoří základní návyky, které prokazatelně vedou $\mathrm{k}$ méně nebezpečnému chování v dílně. Správné zacházení s nástroji, spolupráce žáků i jejich pečlivost vedou ke kvalitnější práci. Ukázalo se, že sami žáci nejsou spokojení s méně kvalitní prací. $\mathrm{Z}$ pečlivěji vykonané práce mají větší radost a více si váží výrobku, který vyrobili.

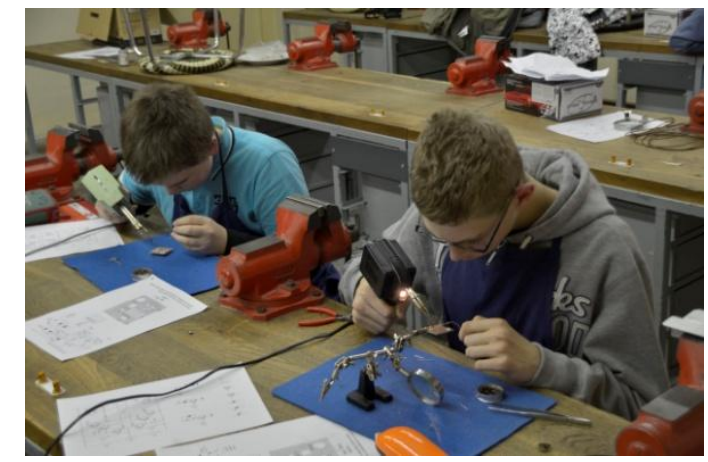

Obr 3: Spolupráce při montáži elektroniky do robota

\section{Závěr}

Výzkum potvrdil předpoklad, že praktická výuka práce $\mathrm{v}$ dílnách $\mathrm{s}$ důsledným a cíleným aplikováním zásad bezpečnosti a ochrany zdraví při práci má výrazně pozitivní vliv na žáky. BOZP vnímají jako integrální součást práce $\mathrm{v}$ dílně, neoddělují ji jako samostatnou oblast.
V konečném důsledku se vlastně naučí pracovat s jejím automatickým dodržováním. Je to cesta přirozená a efektivní. Náročnější je to však pro učitele, který se nemůže a nesmí omezit pouze na řemeslné dovednosti žáků, ale systematicky a trvale musí dbát nejen u žáků, ale také u sebe na dodržování zásad BOZP. I on musí tedy zcela automaticky a přirozeně tyto zásady dodržovat. Bez toho jsou všechny jeho snahy marné. Technická výchova, a především její praktické části, sehrávají důležitou roli $\mathrm{v}$ oblasti bezpečnosti a ochraně zdraví při práci. Na druhou stranu prrispívá také ke kvalitnější odborné práci žáků. Příspěvek vznikl v rámci výzkumného záměru - kód: MSM0021622443, Speciální potřeby žáků v kontextu Rámcového vzdělávacího programu pro základní vzdělávání.

\section{Literatura}

[1] HODIS, Z, STIBOR K. Učební pomůcky a modely. In XXIX International Colloquium on the Management of Educational Process. Brno: Univerzita obrany, 2011. od s. 1-7, 7 s. ISBN 978-80-7231-779-0.

[2] ČERNÁ, L., BRÁCHA, J., MAREK, V., KOCIÁN, J. Bezpečnost a ochrana zdraví při práci ve školách a školských zařízeních. 1. vyd. Brno: MŠMT ČR ve spolupráci s IVBP v Brně, 2002. ISBN 80-85022-29-X.

[3] JABŮRKOVÁ, V., VLČKOVÁ, V. Pedagogický pracovník mezi paragrafy. 1. vyd. Olomouc: Hanex, 2005. 135 s. ISBN 80-8578355-X.

[4] KLOUB, J. Bezpečnost práce v regionálním školství. 1.vyd. Praha: ASPI, 2005. 112 s. ISBN 80-7357-065-3.

Mgr. Martin Kučera

doc. Ing. Jiř́i Hrbáček, Ph.D.

Katedra technické a informační výchovy

Pedagogická fakulta MU

Poříčí 31

60300, Brno, ČR

Tel: +420 549494563

E-mail: 209647@mail.muni.cz

hrbacek@ped.muni.cz

Www pracoviště:

http://www.ped.muni.cz/wtech/ 